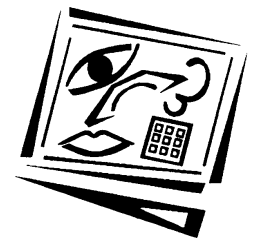

\title{
Experience and beliefs of technology users at an Australian university: Keys to maximising e-learning potential
}

\author{
Gerry Kregor, Monique Breslin and Wendy Fountain \\ University of Tasmania
}

\begin{abstract}
This article reports on a survey of more than 2,300 students and 250 staff members conducted at the University of Tasmania as part of a wider review of e-learning practice, demand and capacity which aims to improve planning, decision-making and the quality of the online experience of students and staff. Data was collected on access to technology, technology usage patterns, and experiences with technology at university. Respondents were also asked for comments on their experiences. Results from the quantitative component are in line with findings from similar recent surveys: high penetration of laptops, wide access to broadband Internet at home, and usage patterns concentrated strongly around common web activities. Differences in usage profiles of some applications can be explained by the difference in lifestyles of students and staff. The two cohorts also exhibit different attitudes towards technology as a result of their different relationship with it in the context of their use of it at university. Many indicated pathways and solutions to imbalances in demand and supply are straightforward and pragmatic. Support of teaching staff is considered crucially important to advancing broader and more effective use of technology at the university.
\end{abstract}

\section{Introduction}

Universities no longer have a choice about whether to implement e-learning: they must in order to remain competitive in the market place (Eynon, 2008; O'Donoghue, Singh \& Dorward, 2001; O'Neill, Singh \& O'Donoghue, 2004). Rather, their choices are about what vision or strategy to adopt and therefore what technology infrastructure and human resources to invest in. The risks involved in getting the mix wrong are farreaching, because e-learning is now at the heart of a university's core business of learning and teaching. There are risks; to the institution's brand if a high quality experience is not delivered (O'Neill, et al., 2004), of wasting significant investment if the technology is under-utilised, and; of disenfranchising staff and students if expectations are not met. The success of a university's e-learning strategy is ultimately in the hands of the users of the technologies implemented to achieve its goals: how deeply they embrace a suite of technologies will determine the impact it has. It is essential then, to understand these users and their relationship with technology in implementing a successful strategy. The way in which users' ideas and beliefs are melded with ideas surrounding a technology is described in Rogers' seminal book Diffusion of innovations (1995) as the 'software' aspect of the technology. This aspect is less visible and less measurable than the hardware aspect, so often receives less attention than hardware issues. 
Various theoretical models have been proposed in the last few decades to explain the process by which technology is adopted (Lewis, Agarwal \& Sambamurthy, 2003; Nicolle \& Lou, 2008; Rogers, 1995; Sun, Tsai, Finger, Chen \& Yeh, 2008; Tabata \& Johnsrud, 2008). A common element in these models is the pivotal role of beliefs of individuals. In general terms, an individual's behaviour is guided by their beliefs (Ajzen \& Fishbein, 1977; Davis, Bagozzi \& Warshaw, 1989; Rogers, 1995); in the case of e-learning, their beliefs about the benefits and difficulties with using the technology guide their intention to make use of it. There are external factors that act to form those beliefs. These could include self-efficacy, or an individual's perceptions of their own capability at using the system (Lewis, et al., 2003; Liaw, Huang \& Chen, 2007; Pituch \& Lee, 2006), perceptions of technology functionality and quality (Pituch \& Lee, 2006; Sun, et al., 2008), or perceptions of social support (Nicolle \& Lou, 2008; Swan, 2001). Analysing these external factors, as well as the attitudes and beliefs created by them, is the first step towards understanding users' behaviour.

Survey data on some of these external factors have been gathered in the last decade. The backdrop for these has been the 'digital native', or 'Net Generation', debate (Bennett, Maton \& Kervin, 2008; Helsper \& Eynon, 2010; Jones, 2010; Kennedy, et al., 2008), in response to Prensky (2001) and Tapscott (1998) where doubt was thrown on teachers' ability to take effective part in the technological transformation because of their 'immigrant' status in a digital world. According to Prensky's model, the generation of individuals born from the early 1980's onwards has new requirements in education that their teachers are struggling to provide, because of a difference in the two groups' use of technology; Prensky postulates that the Net Generation group has little patience for the traditional lecture format, and prefers interaction, instantaneous access, and especially, gaming. This generalisation has been readily adopted by some researchers (Oblinger \& Oblinger, 2005; Oliver \& Goerke, 2007; Veen \& Vrakking, 2006), and also stimulated many studies on student use of technology. A smaller number have also considered the experiences of educators. These studies have failed to produce evidence of a generational divide in terms of IT use, instead finding more variation within age-groups than between.

In the USA, the EDUCAUSE Center for Applied Research (ECAR) has produced an annual survey of 36,000 undergraduates representing mainly traditional, larger institutions, since 2004. Besides showing high levels of ownership and access to IT, the surveys show a normal distribution of adoption amongst students, from laggards to early adopters, dispelling the idea of a uniformly tech-savvy Net Generation. In the UK, The Oxford Internet Survey (Helsper \& Eynon, 2010) interviewed 2,350 members of the general public aged 14 years and older in 2007 about Internet access and use. The study failed to find evidence for a generational divide, but determined that level of experience with the Internet was a better indicator of belonging to a group with Net Generation characteristics. In Australia, the Educating the Net Generation project (Kennedy, et al., 2009; Kennedy, et al., 2008) surveyed 2,588 undergraduates and 108 staff from three institutions. One of the aims of the project was to compare experiences of 'Net Generation' students and their teachers. The study found small age-based differences in mobile phone and 'Web 2.0' technologies - but, 'the data more strikingly provide strong evidence of the great diversity within both staff and student cohorts' (Kennedy, et al., 2009). Also in Australia, Gosper et al. (2011) surveyed 10,277 students at three universities in 2010 on current and preferred usage of technologies. Students stated a preference for increased use of almost all surveyed technologies to support their learning. Hosein et al. (2010) asked whether the frequent use of technologies by 
Net Generation-aged students gave them an advantage over older students when it came to using technologies at university. First year students at five UK universities were surveyed at the start and end of the academic year; the authors found that any competency differences between older and younger students were quite small, and diminished as the year progressed.

Synthesising findings from a number of the largest quantitative surveys we find:

- High levels of access to and ownership of hardware (Corrin, Lockyer \& Bennett, 2010; Gorra, et al., 2010; Jones \& Ramanau, 2009b; Kennedy, et al., 2009; Oliver \& Goerke, 2007; Smith \& Caruso, 2010)

- A diversity of experience and skill levels: more variation within age-groups than between (Corrin, et al., 2010; Eynon \& Malmberg, 2011; Helsper \& Eynon, 2010; Kennedy, et al., 2009; Smith \& Caruso, 2010)

- Near universal use of core technologies such as email, mobile phone and web browsing for information, but low use of emerging ones (Kennedy, et al., 2009; Smith \& Caruso, 2010), (Gosper et al., 2011)

- Some recreational technologies used more by younger individuals (Hosein, et al., 2010; Jones \& Ramanau, 2009a; Kennedy, et al., 2009)

- Stated student preference for learning in traditional ways such as lectures and discussions with instructors (Garcia \& Qin, 2007; Gorra, et al., 2010; Smith \& Caruso, 2010).

Published large-scale surveys seeking to discover student and staff attitudes and beliefs about e-learning are few. Many surveys have been designed to test predictive models involving a selection of external factors and an intention outcome (Lewis, et al., 2003; Liaw, et al., 2007; Pituch \& Lee, 2006; Sun, et al., 2008) and, to that end, the samples are small and not meant to be representative of a general population, and the factors and beliefs included in the study are pre-selected. Lohnes and Kinzer (2007) conducted an ethnographic study using observations of nine students in various settings and interviews to uncover student attitudes towards use of technology in the classroom. They found that despite intensive recreational use of technology, eight out of nine students in the sample had strong preferences for face to face interactions with teachers because of their mental models of ideal learning. The Educating the Net Generation study (Kennedy, et al., 2009) included focus groups and interviews with students and lecturers. They uncovered cases of students not fitting the 'digital native' stereotype, including low confidence in IT use, and for teaching staff they highlighted issues of increased workload, functional limitations of the technology and interface and usability issues. Eynon (2008) conducted 41 interviews with teaching staff to determine motivations for adopting the use of the web for teaching, and difficulties for staff in doing so. Issues raised included lack of time, lack of interest, lack of skill, and course constraints.

Results from the currently reported survey add to the wider literature of student and staff technology usage, and also provide a catalogue of issues arising from and motivating the beliefs of students and staff about e-learning. Based on the findings, we propose transferrable strategies for maximising e-learning potential, that we foresee enduring beyond issues tied to specific of-the-moment technologies. One of the recommended strategies is wider use and adaptation of the staff and student survey, as reported here, developed for the University of Tasmania context. Its design allows for substitution of emergent technologies, any major changes to core systems, as well as shifting attitudinal foci. 


\section{Context of this study}

In 2009 the University of Tasmania undertook an evidence-based review of e-learning in order to inform the University's e-learning strategy under development at the time. The review used the PickEMix e-learning benchmarking methodology (Bacsich, 2009; The Higher Education Academy, 2009) as a framework. Although no interorganisational comparisons were made in the current review, the methodology was nevertheless very useful to impose breadth and rigor on stages of enquiry into the University's current e-learning practice, governance, demand and capacity. The review was conducted over approximately 9 months and involved collection of evidence through a survey of students and staff (the focus of this paper), some focus groups, interviews with approximately 40 staff members and external stakeholders, and analysis of extant documentation.

The e-learning strategy as mentioned above has now been reframed as the 'Technology Enhanced Learning and Teaching (TELT) Action Plan' and has been ratified by Academic Senate as a strand of the 'Learning and Teaching Strategy'. It is consequently planned to repeat a similar review on a regular basis to measure progress, track issues, inform future iterations of the TELT Action Plan, and achieve quality improvement.

\section{Method}

A survey consisting of two separate but closely aligned questionnaires for staff and students was conducted online (using SurveyMonkey) in July, 2009. The two questionnaires had many questions in common to enable comparison, and comprised quantitative and qualitative questions. The questionnaires were designed specifically to serve the broad information needs of the institutional review. The ECAR questionnaires (Smith \& Caruso, 2010) were used as a starting point and were modified to incorporate specific institutional requirements as well as the scope of the PickEMix methodology.

The quantitative questions sought information from students and staff about demographics, access to hardware and the Internet, frequency of use of a range of technologies, and experience with e-learning at the university. Where appropriate, results from the quantitative questions were compared with findings from other studies.

Several questions were open-ended, generating qualitative data. Questions for students sought comments on the learning management system (branded MyLO for 'My Learning Online'), the lecture recording facility and the academic integrity software, on University IT services, and technology services in general. Staff were asked about the learning management system, policy, teaching spaces, training and support, and the student experience (these questions are listed in Appendix 1). The resulting comments amounted to a collection of stated attitudes and beliefs, prompted by the questions. Surveys are an anonymous forum; they are conducive to a 'dumping' of any issues or problems on 'top-of-mind'. The survey was designed to provide data on the current array of issues in relation to technology use for student and staff users.

During analysis it was not practicable to analyse responses under distinct questions, as many respondents 'dumped' their most pressing issues into the first question they were asked, despite later questions being more relevant to some of those issues. 
Responses were grouped into themes (Miles \& Huberman, 1994), framed to reflect areas of concern that influence respondents' experiences of e-learning. The themes were then ranked in order of frequency. The ranking of themes in this way aimed to measure the relative importance of each theme within the catalogue of users' responses. It is, however, an imperfect measure of beliefs of users in the survey samples for a number of reasons: (a) not all attitudes and beliefs held by individual respondents were captured, just the ones that they chose to comment on; (b) comments were partly prompted by the topic of the question (for the specific questions); (c) it cannot be assumed that chosen comments are those most influential in determining users' actions; and (d) some comments were ambiguous or difficult to interpret. While acknowledging these limitations, we claim that the thematic analysis of respondents' comments is a proxy that captures the most pressing, or urgent, issues for users, at the time.

\section{Results}

The response rates were divided as follows between students and staff:

- 2361 student responses (2298 online, 53 paper).

- 267 staff responses (217 teaching, non-teaching 50, all online).

A selection of the results from the survey data are presented here including demographic information for the survey respondents, usage data for selected technologies and responses to statements on the learning management system. The survey generated a total of 1,298 comments from students, and 274 comments from staff. The sample size (n) varies throughout the results as not all respondents answered all questions. Some further analysis of demographics of the respondents is presented in Appendix 2.

\section{Access to technologies}

Respondents were asked whether they had personal access to a range of technologies at home. These technologies are considered to support online access, communication and interaction or the creation and transmission of digital artefacts.

Table 1: Access to hardware devices

\begin{tabular}{|l|c|c|c|c|}
\hline \multicolumn{1}{|c|}{ Hardware technology } & $\begin{array}{c}\text { Staff at home } \\
(\mathrm{n}=269)\end{array}$ & $\begin{array}{c}\text { Staff at work } \\
(\mathrm{n}=269)\end{array}$ & $\begin{array}{c}\text { Student sole } \\
\text { access }(\mathrm{n}=2350)\end{array}$ & $\begin{array}{c}\text { Student shared } \\
\text { access }(\mathrm{n}=2350)\end{array}$ \\
\hline Desktop computer & $62 \%$ & $63 \%$ & $30 \%$ & $37 \%$ \\
\hline Laptop or notebook & $77 \%$ & $61 \%$ & $73 \%$ & $14 \%$ \\
\hline Either desktop or laptop & $94 \%$ & $94 \%$ & $83 \%$ & $43 \%$ \\
\hline Webcam & $53 \%$ & $28 \%$ & $51 \%$ & $14 \%$ \\
\hline Portable MP3 player & $58 \%$ & $26 \%$ & $73 \%$ & $8 \%$ \\
\hline Digital camera & $76 \%$ & $34 \%$ & $76 \%$ & $7 \%$ \\
\hline Digital video camera & $39 \%$ & $22 \%$ & $44 \%$ & $15 \%$ \\
\hline 3G mobile phone & $41 \%$ & $17 \%$ & $50 \%$ & $5 \%$ \\
\hline
\end{tabular}

Oliver and Goerke (2007) tabulated levels of students' ownership of devices from their study along with levels from ECAR 2010 and Educating the Net Generation. Table 2 shows levels of student ownership from this study alongside several other studies. 
Table 2: Student home access to computer and Internet

\begin{tabular}{|c|c|c|c|c|c|c|}
\hline Survey date & 2005 & 2006 & 2007 & 2008 & 2009 & 2010 \\
\hline $\mathrm{N}$ & 412 & 2,588 & 290 & 470 & 2,361 & 36,000 \\
\hline Source & $\begin{array}{l}\text { Oliver \& } \\
\text { Goerke } \\
\text { (2007) }\end{array}$ & $\begin{array}{l}\text { Educating the Net } \\
\text { Generation, Kennedy } \\
\text { et al. (2009) }\end{array}$ & $\begin{array}{l}\text { Oliver \& } \\
\text { Goerke } \\
\text { (2007) }\end{array}$ & $\begin{array}{l}\text { Corrin et al. } \\
(2010)\end{array}$ & This study & $\begin{array}{l}\text { ECAR, Smith } \\
\& \text { Caruso } \\
(2010)\end{array}$ \\
\hline Location & $\begin{array}{l}\text { Perth, } \\
\text { Australia }\end{array}$ & $\begin{array}{l}\text { Melbourne, Wollon- } \\
\text { gong and Charles } \\
\text { Sturt Uni., Australia }\end{array}$ & $\begin{array}{l}\text { Perth, } \\
\text { Australia }\end{array}$ & $\begin{array}{l}\text { Wollon- } \\
\text { gong, } \\
\text { Australia }\end{array}$ & $\begin{array}{l}\text { Tasmania, } \\
\text { Australia }\end{array}$ & United States \\
\hline $\begin{array}{l}\text { Ownership } \\
\text { or access }\end{array}$ & $\begin{array}{l}\text { Own } \\
\text { device }\end{array}$ & $\begin{array}{c}\text { Access } \\
\text { outside uni }\end{array}$ & $\begin{array}{l}\text { Own } \\
\text { device }\end{array}$ & $\begin{array}{c}\text { Own } \\
\text { device }\end{array}$ & $\begin{array}{c}\text { Sole } \\
\text { access }\end{array}$ & $\begin{array}{l}\text { Own } \\
\text { device }\end{array}$ \\
\hline Desktop & -- & $83 \%$ & -- & $61.5 \%$ & $30 \%$ & $45.9 \%$ \\
\hline Laptop & $47.6 \%$ & $65 \%$ & $48.6 \%$ & $73.4 \%$ & $73 \%$ & $83.8 \%$ \\
\hline $\begin{array}{l}\text { Access to } \\
\text { Internet }\end{array}$ & $94.4 \%$ & $95.8 \%$ & $91.4 \%$ & $96.6 \%$ & 92.1\% & -- \\
\hline $\begin{array}{l}\text { Broadband } \\
\text { Internet }\end{array}$ & -- & $76.0 \%$ & -- & $96.6 \%$ & $87 \%$ & -- \\
\hline
\end{tabular}

The majority $(87 \%)$ of students have access to broadband at home, which is an important enabler for access to the majority of online technologies and services, including UTAS learning and teaching systems.

OECD figures (OECD, 2011) indicated that in 2008 62\% of Australian households had access to broadband, therefore from these figures it is apparent that students are more likely to have access to broadband than the general population. This is a demographic phenomenon in line with findings from the Oxford Internet Survey in the UK in 2007 (Helsper \& Eynon, 2010), which found that households containing children and youth have the highest levels of ICT access.

\section{Usage}

The results from survey questions on technology use provided information about the general level of familiarity that staff and students have with a range of common and less common technology applications. The usage profiles give an indication about how readily accepted a technology might be if introduced as an innovation in learning and teaching, or conversely, how much effort would be required to gain acceptance and use of such innovations.

Figure 1 shows that the majority of students and staff were daily or at least regular users of the web for general reference and information searching, online transactions such as banking and shopping, and web-based email.

\section{Experiences of ICT services at university}

\section{General}

The survey data indicated that the majority of students were satisfied with access to computers and the wireless network at UTAS (Figure 2). Quite a large minority (30\%) found their IT skills challenged sometimes by use of technology in courses. Staff were markedly less satisfied with their experience (Figure 3), as 50\% of staff believed that there was inadequate planning and recognition of workload associated with elearning; only 18\% considered it adequate; $42 \%$ regarded learning spaces as not physically suitable for "innovative use of learning technology", compared to $18 \%$ who did. 


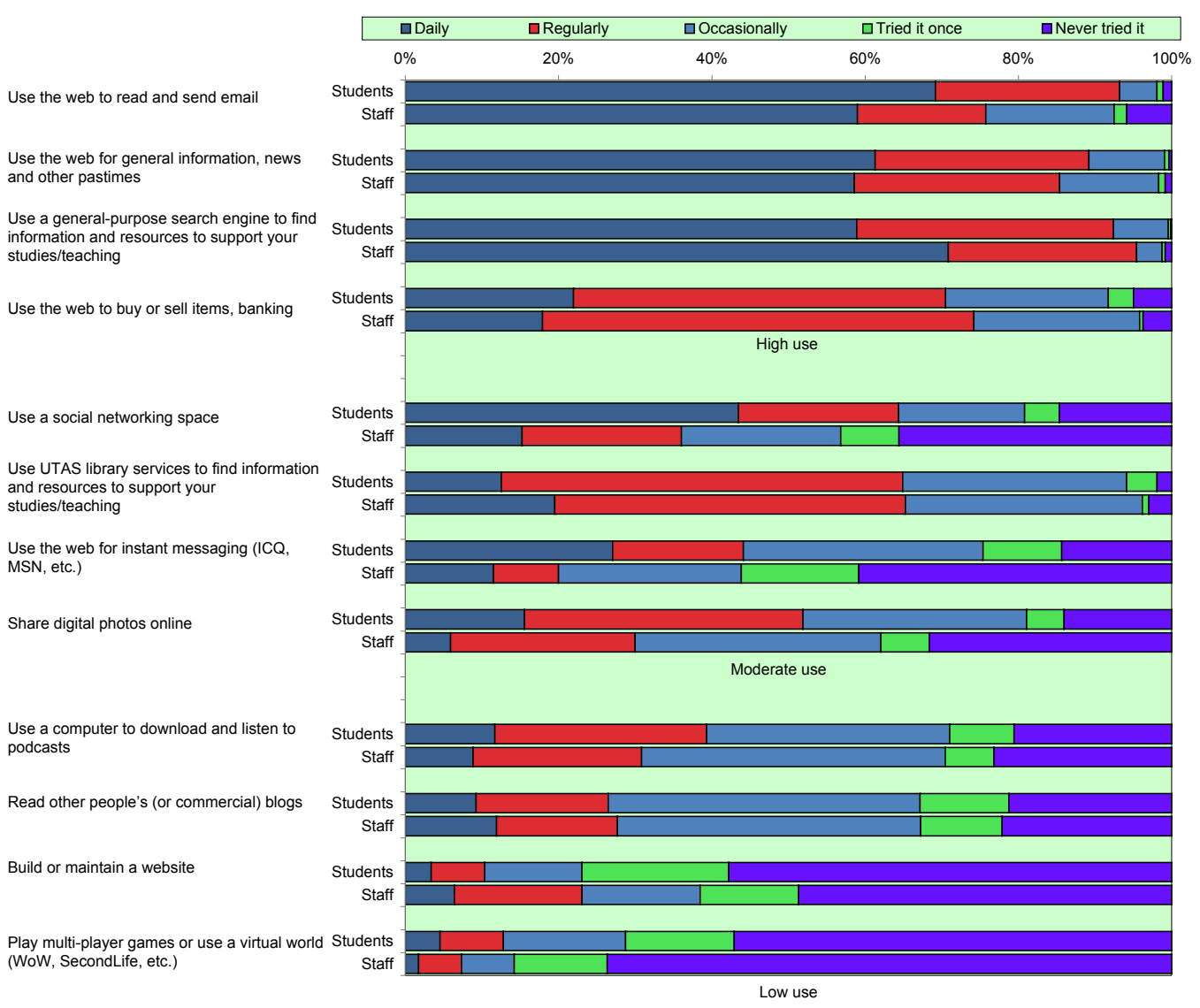

Figure 1: Frequency of use of a range of technology applications for students and staff

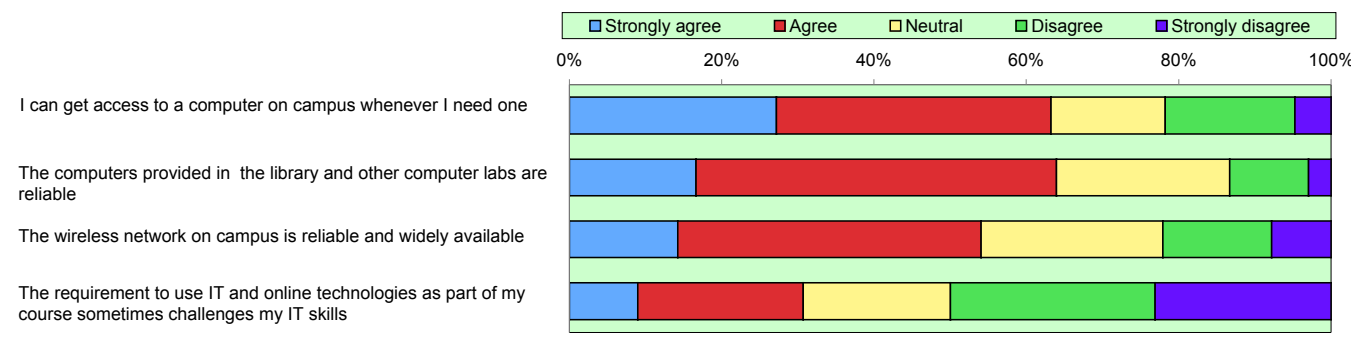

Figure 2: Student responses to statements about aspects of technology at university

Learning management system

The university has deployed a learning management system (LMS) for flexible delivery and course management since 2001. At the time of this study, Blackboard Vista was being used, rebadged for use at the University of Tasmania as MyLO ('My Learning Online'). Responses for questions relating to the LMS were isolated to include only teaching staff $(\mathrm{n}=209)$. 


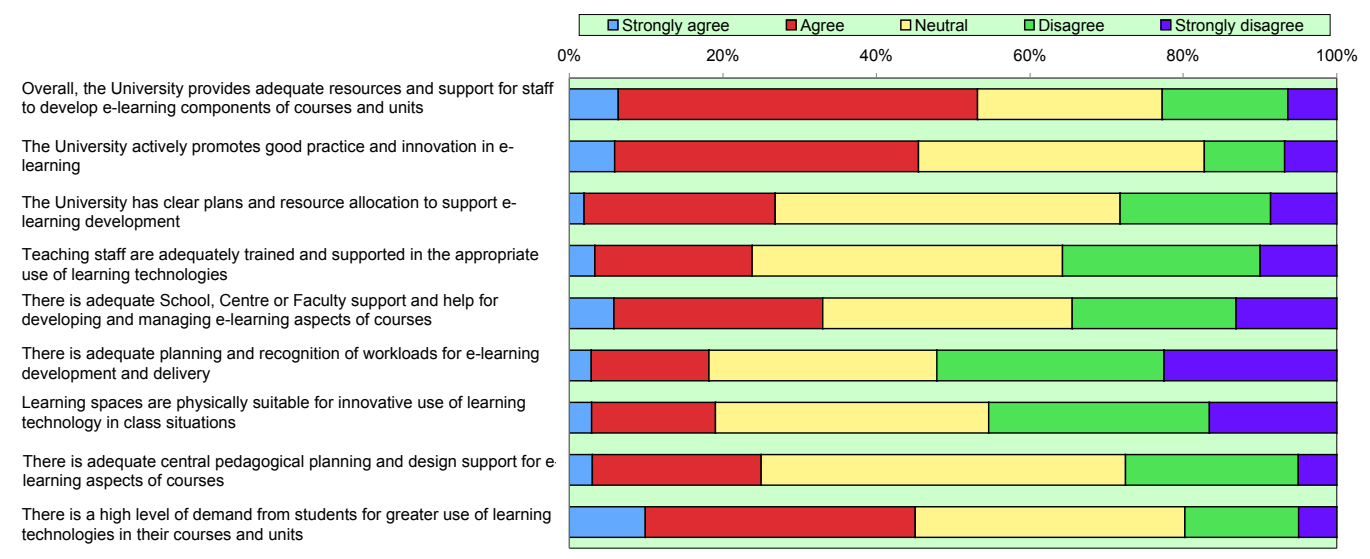

Figure 3: Staff responses to statements about aspects of technology at university

Table 3: Reasons most often cited for using MyLO

\begin{tabular}{|l|c|}
\hline \multicolumn{1}{|c|}{ Reasons for using $M y L O$} & $\%(\mathrm{n}=171)$ \\
\hline It's School/ Department Policy to use $M y L O$ & $64 \%$ \\
\hline To allow access to supplementary resources & $64 \%$ \\
\hline To increase the flexibility of units & $57 \%$ \\
\hline To provide supplementary communication & $57 \%$ \\
\hline To support or deliver some core content, communication or assessment & $55 \%$ \\
\hline $\begin{array}{l}\text { Other: To return marks to students, keep track of marks, track student } \\
\text { engagement, coordinate teaching with other staff, to self-organise }\end{array}$ & $15 \%$ \\
\hline Notes: $\%$ of staff using MyLO: 82\% $(\mathrm{n}=209)$ & \\
\hline
\end{tabular}

Table 4: Reasons most often cited for not using $M y L O$

\begin{tabular}{|l|c|}
\hline \multicolumn{1}{|c|}{ Reasons for not using MyLO } & $\%(\mathrm{n}=38)$ \\
\hline There is simply no compelling reason to use it & $47 \%$ \\
\hline Lack of awareness or training & $32 \%$ \\
\hline It won't support my teaching style & $24 \%$ \\
\hline Workload - it's too time consuming & $24 \%$ \\
\hline $\begin{array}{l}\text { It would be detrimental to my students' approach to the subject } \\
\text { Other: Time to implement, time available for training, part time staff not } \\
\begin{array}{l}\text { supported to attend training, use of other tools such as a wiki, use of a } \\
\text { departmental server }\end{array}\end{array}$ & $21 \%$ \\
\hline Notes: $\%$ of staff not using MyLO: $18 \%(\mathrm{n}=209)$ & \\
\hline
\end{tabular}

The MyLO LMS was being used by $82 \%$ of teaching staff respondents, but the extent of usage was not specified. On being asked to rate their comfort level with using $M y L O$, $68 \%$ felt confident or very confident, $6 \%$ were "just getting by but happy", $16 \%$ were "just getting by and I know I could do more", $6 \%$ were doing "the bare minimum" but happy, 3\% were doing the bare minimum and "could do with more support", and 1\% "avoid using it". Of the $18 \%$ of staff not using $M y L O$, the data indicated some barriers of awareness, support and workload, but there were still $47 \%$ of these $(8 \%$ of total staff) who chose not to use it because they are yet to be convinced of the benefits.

Eighty eight percent of students agreed or strongly agreed that $M y L O$ is "an important service that helps support my study" (Figure 4). This mirrors data from 2009 in The first year experience in Australian universities survey (James, Krause \& Jennings, 2010). Of 
2,228 first year students across nine institutions who used an LMS, $87 \%$ of students found it useful. The three functions of MyLO most appreciated by students at the University of Tasmania were: being able to email lecturers ( $88 \%$ agreed or strongly agreed this is important), having lecture notes and PowerPoints available (84\% agreed or strongly agreed) and having the unit outline available (83\% agreed or strongly agreed). Functions with weaker responses were discussion forums (52\%) and submitting assignments online (55\%), but this is partly attributable to the fact that these aspects are less frequently employed in courses by staff.

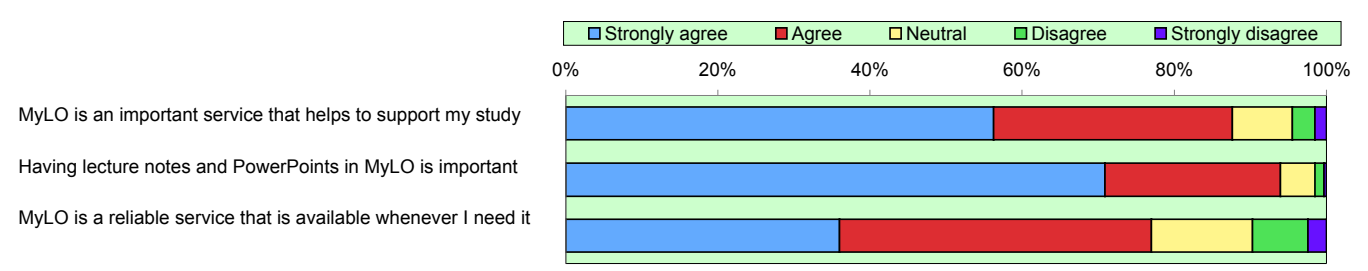

Figure 4: Student opinions on their overall experience of using MyLO

\section{Attitudes to technology}

Students and staff were asked firstly about their overall attitude to technology (AQ1) and the online environment, and secondly about its value to their studies or teaching (AQ2). The full questions are shown in Figure 5, and have been labeled AQ1 and AQ2 here for ease of reference. Both students and staff reported being enthusiastic about ICT and the online environment generally; in both groups around $80 \%$ agreed or strongly agreed (79\% of staff and $85 \%$ of students). There is a marked difference, however, between staff and student attitudes in relation to AQ2; that is for the value of ICT in learning and teaching. Students showed an almost identical level of enthusiasm for ICT in their study environment as they do in general.

Figure 5 shows that teaching staff were somewhat less convinced that the integration of ICT and the online environment in learning and teaching is beneficial to students (70\% of staff agreed or strongly agreed, $83 \%$ of students agreed or strongly agreed). A chi square test and Mann Whitney test with correction for ties (which ranks the sample of responses in the two groups against each other) were performed for both questions to compare the distribution of staff and student responses; results are shown in Figure 5.Both tests confirm that the differences are significant $(p<0.025$ for AQ1, $p<0.001$ for AQ2).

The total proportion of students who agreed to some extent with the benefits of integrating technology in learning is worth emphasising: an overwhelming $94 \%$.

To decouple the effects of age and role on attitudes to ICT in learning, Figure 6 shows staff and student responses to AQ2 for two age-groups. There is no clear effect on responses from age-group; the total proportion of Agree + Strongly agree is almost identical for both age-groups (70\% and $71 \%$ for staff, and $83 \%$ and $85 \%$ for students). Slightly more young staff than older staff strongly agree, but this is balanced by those young staff with a neutral response. In the student sample, more older students than younger students strongly agree. So it seems clear that age is not causing the differences between student and staff responses to AQ2. This suggests that the difference in attitude is due to the roles of students and staff. 


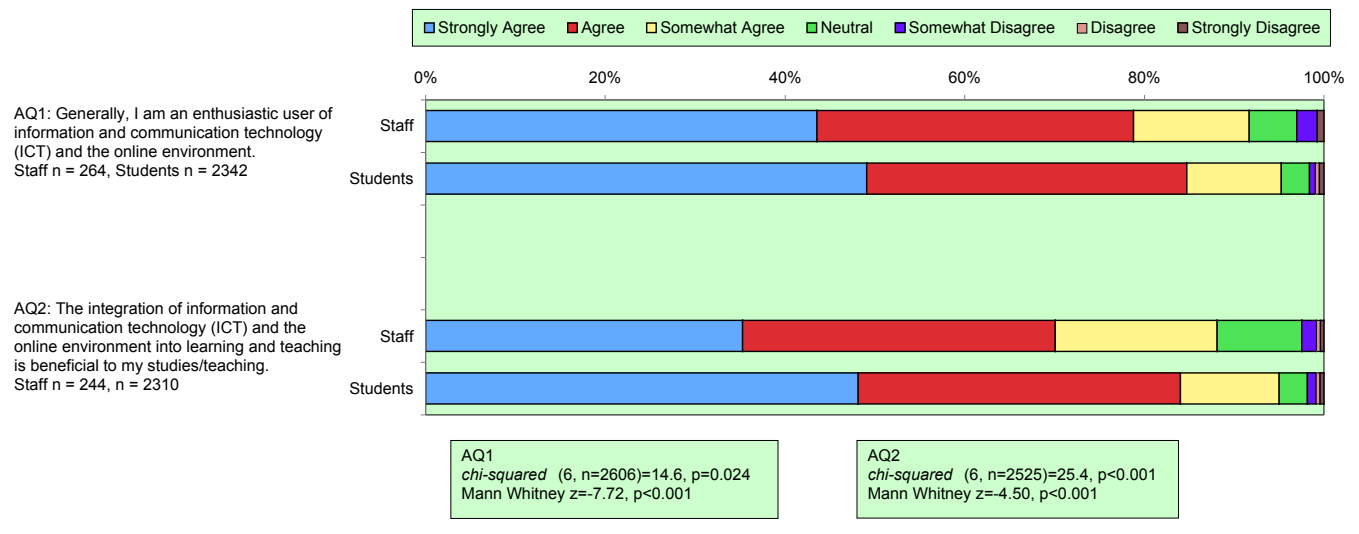

Figure 5: Staff and student responses to questions on general attitude towards technology with statistical tests of difference

Table 5: Responses to AQ2 for staff and student samples, split by age group

\begin{tabular}{|l|c|c|c|c|c|c|}
\hline \multirow{2}{*}{} & \multicolumn{2}{|c|}{ Staff } & \multicolumn{2}{c|}{ Students } & \multicolumn{2}{c|}{ Students } \\
\cline { 2 - 7 } & $\begin{array}{c}<30 \mathrm{yrs} \\
\mathrm{n}=34\end{array}$ & $\begin{array}{c}\geq 30 \mathrm{yrs} \\
\mathrm{n}=202\end{array}$ & $\begin{array}{c}\leq 30 \mathrm{yrs} \\
\mathrm{n}=1,667\end{array}$ & $\begin{array}{c}>30 \mathrm{yrs} \\
\mathrm{n}=663\end{array}$ & $\begin{array}{c}\leq 25 \mathrm{yrs} \\
\mathrm{n}=1,401\end{array}$ & $\begin{array}{c}>25 \mathrm{yrs} \\
\mathrm{n}=928\end{array}$ \\
\hline Strongly agree & $41 \%$ & $36 \%$ & $46 \%$ & $52 \%$ & $46 \%$ & $51 \%$ \\
\hline Agree & $29 \%$ & $35 \%$ & $37 \%$ & $33 \%$ & $37 \%$ & $34 \%$ \\
\hline Somewhat agree & $12 \%$ & $19 \%$ & $11 \%$ & $10 \%$ & $11 \%$ & $10 \%$ \\
\hline Neutral & $18 \%$ & $8 \%$ & $3 \%$ & $3 \%$ & $3 \%$ & $3 \%$ \\
\hline All disagree & $0 \%$ & $2 \%$ & $2 \%$ & $2 \%$ & $2 \%$ & $2 \%$ \\
\hline
\end{tabular}

Student responses were also split at the 25 years age boundary to look for a Net Generation effect in attitudes towards ICT in learning. The pattern for this age-group split is almost identical to that for the 30 years split: that is, Net Generation aged students do not show a stronger preference for technology in learning than their older counterparts.

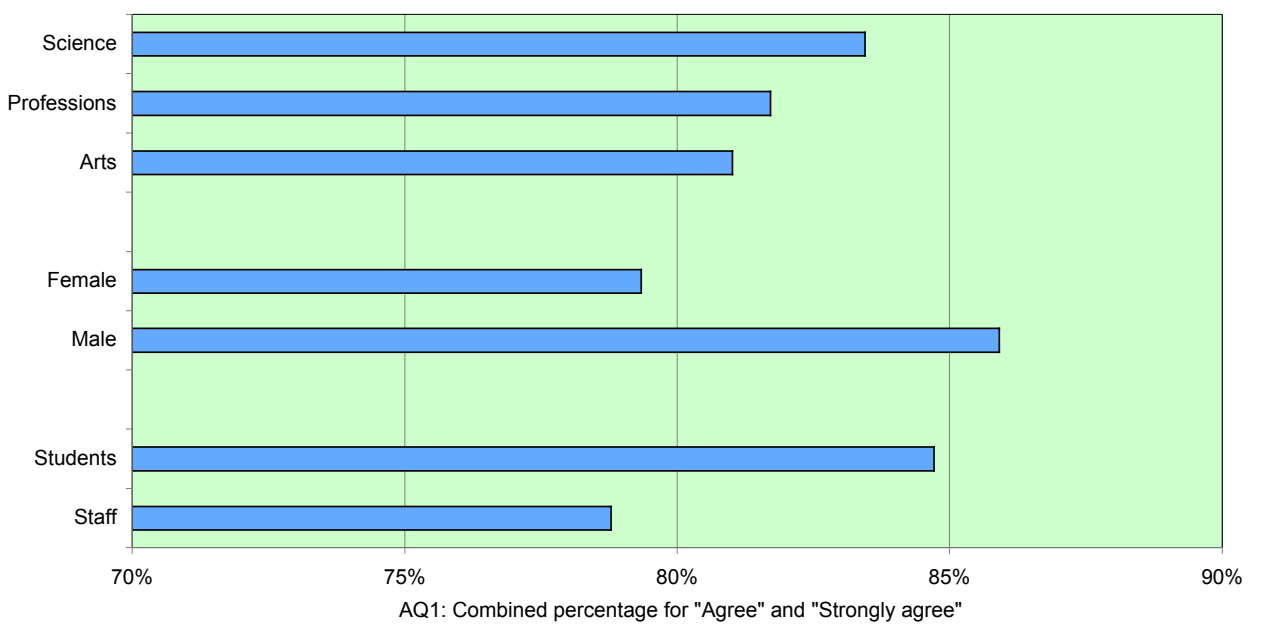

Figure 6: Differences in response to AQ1 for various groups 


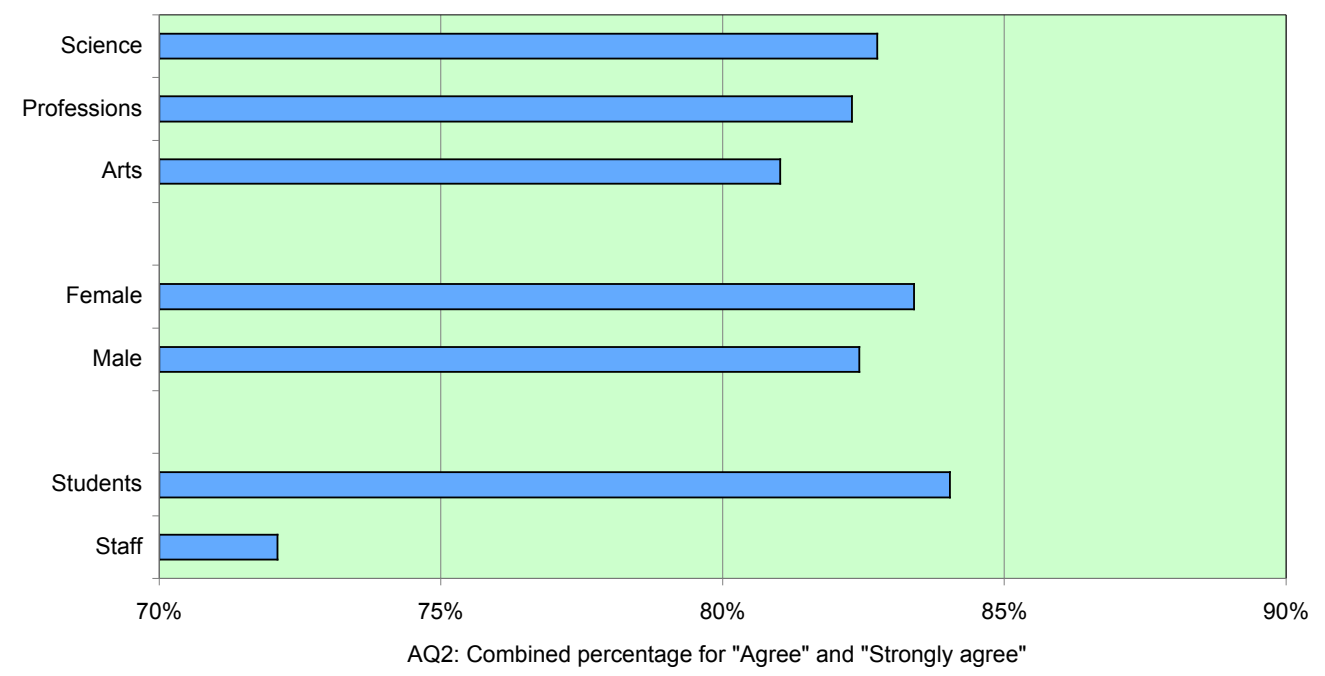

Figure 7: Differences in response to AQ2 for various groups.

Figures 6 and 7 compare the responses to the attitude questions for several different categories. The total percentage of each group that either 'Agreed' or 'Strongly Agreed' is shown. Males are significantly more enthusiastic about ICT in general, but interestingly both genders agreed about the benefits of integrating it in the learning environment. There was a slight association between discipline of study and positive attitude towards ICT, and it was more pronounced for the general question.

\section{Text responses}

\section{Staff themes}

The open-ended questions generated a total of 274 comments from staff. The frequency of comments for the most common themes were: teaching spaces inadequate (47), lack of time and technical support (44), pedagogical outcomes (23), need for more training (20), unreliability (19), and design and functionality of the LMS (16) (Table 6). The issue that generated the highest number of comments, as well as the strongest and most direct language, was the inadequacy of teaching spaces in which learning technology is provided or used. Out of a total of 48 comments on teaching spaces, 47 were negative, and staff seemed to have a lower tolerance for this problem than other problems such as general unreliability or functionality, for example: "woefully provisioned and supported", and "using the computers in $[\mathrm{X}]$ is ridiculously hit and miss." The relative importance to staff of these themes is confirmed by the data in statements on workload and teaching spaces receiving the strongest disagreement.

\section{Student themes}

The open-ended questions generated a total of 1,298 comments from students. The frequency of comments for the most common themes were: generic or specific benefit valued (230), reliability (212), wider and/or fuller use (153), access (108), design and navigation (69), personal interactions with support staff (60) (Table 7). Students were highly appreciative of the benefits they receive from technology at university. Many comments were simple and generic, such as "Keep up the good work". The LMS and lecture recordings were particularly highlighted as beneficial. Negative comments 
mainly related to technical barriers preventing use, such as unreliability or lack of access. There were very few comments expressing resistance towards the principle of using technology in education.

There was a demand for wider use of the LMS and recorded lectures. This is an issue of expectations: when students experience a level of provision in one unit, they reasonably begin to expect it in all.

Table 6: Core themes arising from staff survey text responses

\begin{tabular}{|c|c|}
\hline Staff themes & Examples \\
\hline $\begin{array}{l}\text { Teaching spaces inadequate } \\
\text { The survey question asking specifically about } \\
\text { teaching spaces generated } 61 \text { text comments } \\
\text { compared with approximately } 40 \text { for the other } \\
\text { questions. These most strongly expressed } \\
\text { complaints and frustration. }\end{array}$ & $\begin{array}{l}\text { "AV equipment in lecture theatres and } \\
\text { teaching spaces: out of date, not supported, } \\
\text { difficult to use, not maintained." } \\
\text { "Our current facilities at [X] do not support } \\
\text { the necessary technology teaching methods } \\
\text { we wish to grow." }\end{array}$ \\
\hline $\begin{array}{l}\text { Time resources, skilled e-learning support } \\
\text { The other strong theme was that there are two } \\
\text { principle obstacles to progressing e-learning: } \\
\text { lack of time, and skilled pedagogical and } \\
\text { practical support. Staff seemed positive about } \\
\text { embracing e-learning but lack the time and } \\
\text { resources to do it. Quality support was seen as } \\
\text { vital ingredient for e-learning to progress. }\end{array}$ & $\begin{array}{l}\text { "Please don't force me to do any more } \\
\text { training. Unlike the public service, my } \\
\text { workload won't be adjusted downward to } \\
\text { accommodate it." } \\
\text { "I've discovered myself to be increasingly } \\
\text { reluctant to innovate over the past few years, } \\
\text { since I've not been compensated for the time, } \\
\text { energy and effort put in to distance/ flexible } \\
\text { teaching." }\end{array}$ \\
\hline $\begin{array}{l}\text { Pedagogical outcomes } \\
\text { A strong theme from the survey was staff's } \\
\text { desire for e-learning to serve learning and } \\
\text { teaching, or pedagogical, outcomes. Many were } \\
\text { sceptical of e-learning being used only to } \\
\text { provide online notes and substitute face to face } \\
\text { teaching. }\end{array}$ & $\begin{array}{l}\text { "The real issue for me is the use of } \\
\text { technology to enhance teaching and } \\
\text { learning." } \\
\text { "Evidence that has been talked about to date } \\
\text { does not indicate an improvement in } \\
\text { pedagogical outcomes, just meeting the } \\
\text { needs of students' lifestyles." }\end{array}$ \\
\hline $\begin{array}{l}\text { Training } \\
\text { There was a plea for more training } \\
\text { opportunities: staff state they would use the } \\
\text { system more effectively if given more training. }\end{array}$ & $\begin{array}{l}\text { "It would be good if people could come to } \\
\text { the offices of academic staff and do some one } \\
\text { on one. In the long run that would really } \\
\text { raise the use of the system and greatly } \\
\text { benefit student learning (I think)." } \\
\text { "It is just assumed that we'll work out the } \\
\text { best ones to use (and how to use them) on } \\
\text { our own. Some advice from [educational } \\
\text { developers] would be awesome." }\end{array}$ \\
\hline $\begin{array}{l}\text { Unreliability of technologies } \\
\text { The perceived lack of reliability of e-learning } \\
\text { technologies caused staff to feel frustrated and } \\
\text { pessimistic, most notably for cross-campus } \\
\text { communication and lecture recording. }\end{array}$ & $\begin{array}{l}\text { "Students constantly complain about } \\
\text { videolink, with good reason, I must say." } \\
\text { "Constant complaints of Lectopia cutting off } \\
\text { the end of lectures." }\end{array}$ \\
\hline $\begin{array}{l}\text { Design, current functionality } \\
\text { Issues with the design of the LMS }\end{array}$ & $\begin{array}{l}\text { "The current interface is very clunky" } \\
\text { "Rather than creating possibilities for } \\
\text { e-learning, it constrains the possibilities into } \\
\text { a document storage device..." }\end{array}$ \\
\hline
\end{tabular}


Table 7: Core themes arising from student survey text responses

\begin{tabular}{|c|c|}
\hline Student themes & Examples \\
\hline $\begin{array}{l}\text { Benefits of technology } \\
\text { The LMS is very valuable as a study enabler - to } \\
\text { organise content and give flexibility. It is } \\
\text { absolutely critical for some students who juggle } \\
\text { study with other commitments. } \\
\text { There was great enthusiasm for Lectopia } \\
\text { (recorded lectures) and an overwhelming } \\
\text { request for more/all lectures to be recorded and } \\
\text { made available. }\end{array}$ & $\begin{array}{l}\text { "Fantastic. Makes It possible to return to } \\
\text { study." } \\
\text { "Recorded lectures and Lectopia are brilliant } \\
\text { and assist my studies greatly." } \\
\text { "It is paramount to my studies currently as I } \\
\text { cannot get to campus all the time." }\end{array}$ \\
\hline $\begin{array}{l}\text { Reliability and quality } \\
\text { Including reliability of Wi-Fi, quality of lecture } \\
\text { recordings, compatibility of } M y L O \text { with web } \\
\text { browsers, slow download speeds, and slowness } \\
\text { of on-campus computers. (These are in the } \\
\text { context of more positive general comments } \\
\text { about services.) }\end{array}$ & $\begin{array}{l}\text { "Wireless IT services should be enhanced, } \\
\text { sometimes the wireless drops off my laptop } \\
\text { when in a dedicated wireless area such as a } \\
\text { computer lab. This is not acceptable!" } \\
\text { "The Lectopia recordings tend to be scratchy } \\
\text { and difficult to hear." } \\
\text { "I have found UTAS IT services to be one of, } \\
\text { if not the best I have encountered. Keep up } \\
\text { the excellent work." }\end{array}$ \\
\hline $\begin{array}{l}\text { Wider use of technology } \\
\text { There were requests for LMS and Lectopia for all } \\
\text { subjects, and for a greater range of tools } \\
\text { available within LMS used more effectively, also } \\
\text { keeping content up to date. } \\
\text { The overwhelming majority of feedback } \\
\text { requested broader use of core LMS technology, } \\
\text { with a few sceptical, or desiring both face to face } \\
\text { and online. }\end{array}$ & $\begin{array}{l}\text { "On average } 50 \% \text { of my subjects are on } \\
M y L O, \text { all subjects should be added to } \\
M y L O \text {, as } M y L O \text { is a very useful tool." } \\
\text { "IT is good, but the ability of teaching staff } \\
\text { to use and engage with the technology is not } \\
\text { always as good." }\end{array}$ \\
\hline $\begin{array}{l}\text { Access } \\
\text { Greater access to hardware and infrastructure } \\
\text { was requested - more computers, more power } \\
\text { points for laptops, expanded and simplified Wi- } \\
\text { fi access, access to Wi-fi with mobile phones, } \\
\text { and more computers available in peak times. }\end{array}$ & $\begin{array}{l}\text { "Number of computers on campus is } \\
\text { pathetic. Trying to get access to them when } \\
\text { needed has been one of the most frustrating } \\
\text { aspects of my university experience." } \\
\text { "More Wi-fi areas please." }\end{array}$ \\
\hline $\begin{array}{l}\text { Design, navigability } \\
\text { Improved design and navigation for the } \\
\text { university website and LMS were requested. } \\
\text { Comments were made on layout, presentation } \\
\text { and navigation of the LMS - some good, the } \\
\text { majority negative. There was also demand for } \\
\text { greater consistency in layout across different } \\
\text { units. }\end{array}$ & $\begin{array}{l}\text { "A more consistent approach across subjects } \\
\text { in the utilisation of } M y L O \text { would be nice. To } \\
\text { explain: every subject that's on } M y L O \text { that I } \\
\text { access is set up differently, looks different, } \\
\text { etc., causing confusion and makes it hard to } \\
\text { find the right information." }\end{array}$ \\
\hline $\begin{array}{l}\text { Personal interactions with staff } \\
\text { The face to face experience was declared } \\
\text { important: students were either very thankful, } \\
\text { or resentful about a bad experience. }\end{array}$ & $\begin{array}{l}\text { "Having a name to communicate to, and } \\
\text { frequent correspondence with that person } \\
\text { for glitches is important in reducing stress." } \\
\text { "... staff have always been courteous and } \\
\text { very helpful." }\end{array}$ \\
\hline
\end{tabular}




\section{Discussion}

These results provide an expansive and textured picture of student and staff experience with technology at UTAS. In discussing the results we are keen to make visible the state of the social embedding of e-learning technologies, drawing on Rogers (1995, p.13), in interplay with the software and hardware systems he refers to as the 'machinery'. We also highlight key operational and strategic issues below that we suggest are likely to be transferable to other institutions.

On this basis, the 2009 results first enabled an operational response to 'burning issues' made visible from the analysis, such as the reliability of technology in teaching spaces, and the ineffective and fragmented nature of some support services. However, we were also able to identify further complex issues that had strategic and quality implications:

- The variability of experience for both students and staff, in areas of access and usage, raising questions of equivalence and equity;

- The identification of critical impact points, for example, the patchiness of just-intime support for staff, and LMS use by individual staff strongly determining students' experience (despite operating an enterprise level system);

- A demand to reconceptualise teaching spaces as composites of physical space, technology, students, staff and their interactions; and

- The existence of 'concurrent realities' in the sense that student and staff user experiences differ and deviate from other 'realities' presented by system metrics, numbers of support personnel or the existence of training and support services.

We elaborate on these and other emergent issues further, as they intersect with the broad categories of results: access and usage, user capability and support, and attitudes and beliefs.

\section{Access and usage}

The data show wide access to both hardware and Internet connection at home. Laptops have become increasingly popular in recent years (Smith \& Caruso, 2010) and look set to be standard equipment for many students. MP3 players and digital cameras are also widely used. The survey results confirm that almost all users have integrated the web into their daily life, using it frequently for communicating, sharing images, finding information and buying or selling. It confirms that both students and staff feel at home with the web as an environment to carry out such tasks. This makes it potentially a 'comfortable' or natural environment for academic-related tasks as well - for most staff respondents and the majority of students who are not overly challenged by using ICT in their studies (see Figure 2).

While students and staff both make frequent use of social networking, instant messaging and share digital photos via the web, students are significantly greater users of these more 'mainstream' and socially-oriented Web 2.0 technologies. This mirrors other studies that find a greater use of technology for social and entertainment purposes for younger age groups (Helsper \& Eynon, 2010; Hosein, et al., 2010). In contrast, results indicate that staff are more likely to maintain a website, use library information services and contribute to a wiki - tools that are well-suited to academic work and participating in professional or research networks. It would be expected that 
the different activities and imperatives of students and staff (though diverse within those groups) would be reflected in their technology use profile. Interestingly, the ECAR studies (Smith \& Caruso, 2010) note that the gap between usage of social networking for age-groups has been closing rapidly between 2007 and 2010.

The proposition of the Prensky model (Prensky, 2001) prompted empirical inquiry in our setting, however the 'digital immigrant' vs. 'digital native' dichotomy is not supported by our results. Rather the evidence suggests a spectrum of access and usage preferences for both students and staff. We speculate that what might be more instructive strategically is consideration of the high use technologies for both groups and the expectations that might be generated by this use for the University's systems. For example, Web 2.0 technologies exhibit distinct functionality and usability compared with earlier web tools such as that of a HTML frames-based LMS. This could well explain students' criticisms of LMS navigation and browser compatibility and present an example of the 'concurrent realities' potentially at play, in this case arising from experience-related expectations.

Further, future focus on evidence of convergence in technology use by students and staff may well identify opportunities to enhance learning and teaching with technology in targeted ways. We also note that student and staff roles are more fluid than survey categories reveal: we know that some students may dually have sessional teaching roles or professional experience, staff may be studying in tandem with teaching, and many staff are parents of children and young adults whose technology use they mediate. These factors are precisely the kind of foci that could be updated in the next iteration of the survey.

Alongside such convergence persists the issue of variability of experience, namely in relation to LMS use by students ( $88 \%$ find it useful) and the range of reasons for using and not using MyLO expressed by staff (see Table 3 and Table 4). We are not suggesting that variability is inherently negative; staff should not be encouraged towards 'cookie cutter' standardisation nor discouraged from using idiosyncratic and targeted LMS approaches in our view. However, our concern is for potential equivalence or equity implications, for example where on campus students receive better provision than off campus students, or where taking a course/program rather than a unit/subject level approach could regularise key aspects of experience and encourage staff on course teams to share good learning and teaching practice.

Operationally, the results highlight the blurring of personal technologies, e.g. laptops and smart phones (and latterly tablets such as iPads) with University-provided systems and infrastructure, in addition to cloud-based services. Such blurring has already been acknowledged via the investment in Wi-Fi infrastructure, for which there was significant extra demand expressed in the survey results. Taking a strategic view, we expect this 'permeability' of systems and infrastructure to continue and the university's responsiveness to it to impact heavily on user experience for both students and staff.

\section{User capability and support}

Further results pertinent to user experience are the declared skill levels of students and staff. Studies highlight that self-efficacy, or an individual's perception of their capability at using a technology, is an important factor for their intentions around use 
(Lewis, et al., 2003; Pituch \& Lee, 2006). For student respondents, a significant proportion $(30 \%)$ feel the requirement to use IT and online technologies challenges their IT skills.

This foregrounds the important role of support and training for students; despite being regular web users there are evidently challenges bound up in its application to academic study. It may be that the challenges relate to configuring computers, downloading software, interpreting systems feedback and non-performance. Our results do not identify whether such challenges might also be associated with relatively complex tasks such as using the Library's online databases and locating electronic journal articles. Such tasks could be conflated in the survey response to using technology broadly. Another perspective may be that although students, at times, experience breaks in the technology chain between them and their learning experiences, they are tolerant of this as 'par for the course' with technology and overall these challenges did not prevent students from having a positive attitude towards using technology in learning, given that $94 \%$ agreed to some extent that it is beneficial to them. When students have encountered problems, they were mostly satisfied with the support received.

The self-efficacy factor for staff was addressed by one question in the survey seeking the comfort levels of staff with the LMS (see learning management system section). Thirty two percent were less than confident, again underlining the important role of training and support for a satisfactory staff experience, as well as operationally and strategically. But this also reflects the spectrum of LMS use by staff given that it is not mandated across the institution and that its most intensive use is centred around large cohort courses taught on campus and fully online courses. This connects with the issue of variability for students, as they may well undertake units offered by different schools and faculties as a result of course structures and electives. Or, they may simply take units taught by different staff electing to use the LMS in differing ways.

\section{Attitudes and beliefs}

While the survey explicitly sought the attitudes and beliefs of students and staff in relation to their experience of technology, we underestimated how crucially these would reveal and inform operational and strategic considerations at UTAS. Beyond the general convergence in technology use and enthusiasm for it expressed by students and staff (see AQ1, Figure 5), a significant divergence in attitudes and beliefs relating to technology in the academic setting emerged for the two groups.

For example, there was a marked difference in attitudes towards ICT in learning and teaching (see AQ2 student/staff response in Figure 7). That is, students were more positive towards the benefits of e-learning than their teachers. Splitting the samples by age group showed that the difference in attitude was not aligned with age, again dispelling a generational divide. We therefore attribute the difference to respective roles where time saving and flexibility gains for students may inversely require additional workload or skill demands for some staff. It is self-evident that the two groups have very different relationships with the technology as a function of role. The LMS, for example, typically positions staff as creators/developers and students as users/consumers, so that the two groups experience the same system in different ways, and this forms the basis for their attitudes and beliefs. 
Errington (2004) argued for the importance of teacher beliefs in the take up of technology in the classrooms and suggested, "The 'infrastructure' for flexible learning innovation exists as much at the level of dispositions as it does on any physically resourced plane." The factors influencing the attitudes of staff are articulated clearly in the open text responses of the survey (see Table 6) and the quantitative data on experience of university ICT services (Figure 3). Staff were broadly enthusiastic about the potential of e-learning, but did not widely regard the fulfillment of this potential as operationally possible at the time of the survey. System reliability, workloads, and training and support provision were all identified as barriers, despite recognition of the demand from students.

An overwhelming message from staff was a desire to see e-learning serve pedagogical goals. Staff on the whole were positive about the potential for e-learning to provide new opportunities to enhance learning and teaching, but were wary of using technology for its own sake, disappointed if its primary role was content delivery, and some were sceptical that its use would replace face to face teaching, to students' detriment. In short, the value expressed was for a quality solution that in practice would demand a highly integrated strategic response.

The staff attitudes expressed in relation to teaching spaces also sharply dispelled any neat division between e-learning systems and face to face provision, that might have been the basis for operational decision making in the past. The criticisms of teaching spaces and the reliability of the technologies within them provoked two new conceptions critical for operational and strategic planning. The first was that 'elearning' needed to be understood institutionally as happening everywhere, that is, irrespective of mode of study. Coupled with this, teaching spaces and technology needed to be understood as being indivisible. The Next Generation Learning Spaces project (University of Queensland, 2011) demonstrates the wider priority in the sector for spaces that support contemporary learning and teaching approaches, in which technology is integral and extensible.

In contrast, students are very positive towards the role of technology in facilitating their access to study and, in the main, towards the university's provision to that end. In Rogers' terms (1995) the social embedding of technologies by and for students has been more pervasive to date than for staff. Interestingly, students did not voice a demand for innovation such as the emerging technologies among those grouped as low use in Figure 1, though we note this preference may have shifted since 2009. Students clearly indicated they wanted the current provision to work better and they wanted consistent and pervasive (even universal) access.

The survey results foregrounded the variability of experience for the student and staff respondent groups at UTAS, and how the systems and the provision of e-learning are in effect only as positive or negative as the sum of users' attitudes and beliefs. Consequently, the initial response at an institutional level was to prioritise the points of critical impact, providing 'first aid' in a sense, as any new strategic vision was unlikely to be shared by staff members experiencing acute vexation on a weekly basis due to unreliable 'machinery' and circuitous support channels. Similarly, responding to the $30 \%$ of students for whom using ICT in their studies was a challenge required both an immediate and strategic response in terms of support.

The welcoming of these findings by senior management at UTAS and the endorsement of the ensuing Technology Enhanced Learning and Teaching (TELT) Action Plan has 
been a major step towards improving the student and staff experience of technology at the university. It is planned to repeat the surveys as part of a similar review on a regular basis to measure progress, track issues and inform future iterations of the TELT Action Plan and achieve quality improvement.

\section{Conclusion}

Results from the quantitative components of these surveys are in line with findings from similar recent surveys: high penetration of laptops, wide access to broadband Internet at home, usage patterns concentrated strongly around common web activities. Differences in usage profiles between staff and students, of some applications, can be explained by the difference in lifestyles rather than role. The two cohorts also exhibit different attitudes towards technology as a result of their different relationship with it in the context of their use of it at university.

Conducting a survey of this scale and ensuring its results and analysis became embedded in strategy and action was a resource-intensive undertaking. However, the survey results, along with coordinated focus groups, interviews and documentary reviews, using a structured methodology, contributed to an unprecedented evidence base for e-learning decision-making at UTAS.

The key outcomes can be expressed in the form of recommendations relevant to institutions sharing our goal to maximise e-learning potential:

1. Identify the critical impact points in student and staff experience in current elearning operations as a matter of priority. In this case, swiftly addressing the reliability of technology in teaching spaces and streamlining support had high affective value for staff and positive flow-on benefits for students.

2. Identify and redress variability in experience with equivalence and equity implications arising, for example, from different study modes and multi-campus access to technology.

3. In developing strategies for teaching spaces, devise support that acknowledges that the practices with technology in teaching spaces are now distributed, for example, via lecture recordings that also serve as content in online courses.

4. In the absence of an existing evaluation strategy, draw on methods such as those used in this case to capture baseline institutional data as a first step in ongoing evaluation. This may also prepare an institution to participate in quality enhancing e-learning benchmarking activities.

5. Explicitly address the social embedding of technology for all users, irrespective of role. Our results reflecting the attitudes and beliefs of users suggest that the pursuit of a student-centred experience has to some extent been at the expense of staff. This is clearly an unsustainable imbalance in the longer term.

\section{References}

Ajzen, I. \& Fishbein, M. (1977). Attitude-behaviour relations: A theoretical analysis and review of empirical research. Psychological Bulletin, 84(5), 888-918.

http: / / psycnet.apa.org/doi/10.1037/0033-2909.84.5.888 
Bacsich, P. (2009). New beta version of Pick\&Mix benchmarking system released. eLearning compendia, weblog post, 27 May 2009 [viewed 11 Jun 2009, verified 22 Oct 2012] http:/ / bacsich.typepad.com/elearning/2009/05/new-beta-version-of-pickmixbenchmarking-system-released-.html

Bennett, S., Maton, K. \& Kervin, L. (2008). The 'digital natives' debate: A critical review of the evidence. British Journal of Educational Technology, 39(5), 775-786. http: / / dx.doi.org/10.1111/j.1467-8535.2007.00793.x

Corrin, L., Lockyer, L. \& Bennett, S. (2010). Technological diversity: An investigation of students' technology use in everyday life and academic study. Learning, Media and Technology, 35(4), 387-401. http: / / dx.doi.org/10.1080/17439884.2010.531024

Davis, F. D., Bagozzi, R. P. \& Warshaw, P. R. (1989). User acceptance of computer technology: A comparison of two theoretical models. Management Science, 35(8), 982-1003. http: / / dx.doi.org/10.1287/mnsc.35.8.982

Errington, E. (2004). The impact of teacher beliefs on flexible learning innovation: Some practices and possibilities for academic developers. Innovations in Education and Teaching International, 41(1), 39-47. http:/ / dx.doi.org/10.1080/1470329032000172702

Eynon, R. (2008). The use of world wide web in learning and teaching in higher education: Reality and rhetoric. Innovations in Education and Teaching International, 45(1), 15-23. http: / / dx.doi.org/10.1080/14703290701757401

Eynon, R. \& Malmberg, L.-E. (2011). A typology of young people' Internet use: Implications for education. Computers \& Education, 56(3), 585-595. http: / / dx.doi.org/10.1016/j.compedu.2010.09.020

Garcia, P. \& Qin, J. (2007). Identifying the generation gap in higher education: Where do the differences really lie? Innovate, 3(4). http: / / www.innovateonline.info/index.php?view=article\&id=379

Gorra, A., Finlay, J., Devlin, M., Lavery, J., Neagle, R., Sheridan-Ross, J., Charlton, T. \& Boyle, R. (2010). Learning with technology: What do students want? Paper presented at the 5th International Conference on e-Learning, July 2010, Penang, Malaysia. [verified 22 Oct 2012] http: / / books.google.com.au / books?id=8wRIjaxTQjkC\&pg=PA126\&lpg=PA126

Gosper, M., Malfroy, J., McKenzie, J. \& Rankine, J. (2011). Students' engagement with technologies: Implications for university practice. In Changing demands, changing directions. Proceedings ascilite Hobart 2011. (pp.504-508).

http: / / www.ascilite.org.au/conferences / hobart11/ downloads / papers / Gosper-concise.pdf

Helsper, E. \& Eynon, R. (2010). Digital natives: Where is the evidence? British Educational Research Journal, 36(3), 503-520. http: / / dx.doi.org/10.1080/01411920902989227

Hosein, A., Ramanau, R. \& Jones, C. (2010). Learning and living technologies: A longitudinal study of first-year students' frequency and competence in the use of ICT. Learning, Media and Technology, 35(4), 403-418. http:/ / dx.doi.org/10.1080/17439884.2010.529913

James, R., Krause, K.-L. \& Jennings, C. (2010). The first year experience in Australian universities: Findings from 1994 to 2009. Centre for the Study of Higher Education, The University of Melbourne. http:/ / www.cshe.unimelb.edu.au/research/FYE_Report_1994_to_2009.pdf

Jones, C. (2010). A new generation of learners? The Net Generation and digital natives. Learning, Media and Technology, 35(4), 365-368. http: / / dx.doi.org/10.1080/17439884.2010.531278

Jones, C. \& Ramanau, R. (2009a). Collaboration and the Net Generation: The changing characteristics of first year university students. In Computer Supported Collaborative Learning Practices, 8-13 June 2009, Rhodes, Greece. http:/ / oro.open.ac.uk/18689/ 
Jones, C. \& Ramanau, R. (2009b). The Net Generation enters university: What are the implications for technology enhanced learning? In M-2009: Proceedings of the 23rd ICDE World Conference on Open Learning and Distance Education. 7-10 June, Maastricht, NL.

Kennedy, G., Dalgarno, B., Bennett, S., Gray, K., Waycott, J., Judd, T., et al. (2009). Educating the Net Generation: A handbook of findings for practice and policy. The University of Melbourne. http: / / www.netgen.unimelb.edu.au/outcomes/handbook.html

Kennedy, G., Dalgarno, B., Bennett, S., Judd, T., Gray, K. \& Chang, R. (2008). Immigrants and natives: Investigating differences between staff and students' use of technology. In Hello! Where are you in the landscape of educational technology? Proceedings ascilite Melbourne 2008. http: / / www.ascilite.org.au/conferences/melbourne08/procs/kennedy.pdf

Lewis, W., Agarwal, R. \& Sambamurthy, V. (2003). Sources of influence on beliefs about information technology use: An empirical study of knowledge workers. MIS Quarterly, 27(4), 657-678. http: / / misq.org/ sources-of-influence-on-beliefs-about-information-technology-usean-empirical-study-of-knowledge-workers.html

Liaw, S.-S., Huang, H.-M. \& Chen, G.-D. (2007). Surveying instructor and learner attitudes toward e-learning. Computers $\mathcal{E}$ Education, 49, 1066-1080. http: / / dx.doi.org/10.1016/j.compedu.2006.01.001

Lohnes, S. \& Kinzer, C. (2007). Questioning assumptions about students' expectations for technology in college classrooms. Innovate, 3(5). http:/ / www.innovateonline.info/ pdf / vol3_issue5/Questioning_Assumptions_About_Students'_Expectations_for_Technology_in_ College_Classrooms.pdf

Miles, M. B. \& Huberman, A. M. (1994). Qualitative data analysis: An expanded sourcebook. Thousand Oaks, CA: SAGE.

Nicolle, P. \& Lou, Y. (2008). Technology adoption into teaching and learning by mainstream university faculty: A mixed methodology study revealing the "How, when, why and why not". Journal of Educational Computing Research, 39(3), 235-265. http: / / dx.doi.org/10.2190/EC.39.3.c

O'Donoghue, J., Singh, G. \& Dorward, L. (2001). Virtual education in universities: A technological imperative. Journal of Information Technology Education, 32(5), 511-523. http: / / dx.doi.org/10.1111/1467-8535.00221

O'Neill, K., Singh, G. \& O'Donoghue, J. (2004). Implementing elearning programmes for higher education: A review of the literature. Journal of Information Technology Education, 3, 313-323. http: / / www.jite.org/ documents/Vol3/v3p313-323-131.pdf

Oblinger, D. \& Oblinger, J. (2005). Educating the Net Generation. EDUCAUSE. http:/ / www.educause.edu/educatingthenetgen/

OECD (2011, 28 Jun 2011). Households with broadband access, 2000-2010. [viewed 4 Nov 2011, verified 22 Oct 2012] http: / / dx.doi.org/10.1787/888932399088

Oliver, B. \& Goerke, V. (2007). Australian undergraduates' use and ownership of emerging technologies: Implications and opportunities for creating engaging learning experiences for the Net Generation. Australasian Journal of Educational Technology, 23(2), 171-186. http:// www.ascilite.org.au/ajet/ajet23/oliver.html

Pituch, K. \& Lee, Y.-K. (2006). The influence of system characteristics on e-learning use. Computers \& Education, 47(2), 222-244. http:/ / dx.doi.org/10.1016/j.compedu.2004.10.007 
Prensky, M. (2001). Digital natives, digital immigrants. On The Horizon, 9(5), 1-6. http: / / www.marcprensky.com/writing/prensky\%20-

\%20digital\%20natives, \%20digital\%20immigrants\%20-\%20part1.pdf

Rogers, E. M. (1995). Diffusion of innovations (Fourth ed.). New York: The Free Press.

Smith, S. \& Caruso, J. (2010). The ECAR study of undergraduate students and information technology, 2010 - key findings. EDUCAUSE Center for Applied Research. http:/ / www.educause.edu / library/ resources / ecar-study-undergraduate-students-and-information-technology-2010

Sun, P.-C., Tsai, R. J., Finger, G., Chen, Y.-Y. \& Yeh, D. (2008). What drives a successful elearning? An empirical investigation of the critical factors influencing learner satisfaction. Computers E Education, 50(4), 1183-1202. http:/ / dx.doi.org/10.1016/j.compedu.2006.11.007

SurveyMonkey. http:/ / www.surveymonkey.com/

Swan, K. (2001). Virtual interaction: Design factors affecting student satisfaction and perceived learning in asynchronous online courses. Distance Education, 22(2), 306-331. http: / / dx.doi.org/10.1080/0158791010220208

Tabata, L. N. \& Johnsrud, L. K. (2008). The impact of faculty attitudes toward technology, distance education, and innovation. Research in Higher Education, 49(7), 625-646. http: / / dx.doi.org/10.1007/ s11162-008-9094-7

Tapscott, D. (1998). Growing up digital: The rise of the Net Generation. McGraw-Hill.

The Higher Education Academy (2009). Pick\&Mix. Wiki page [viwed 11 June 2009]. http:/ / elearning.heacademy.ac.uk/wiki/index.php/Pick\&Mix

University of Queensland (2011). Next generation learning spaces. http:// www.uq.edu.au/nextgenerationlearningspace/

Veen, W. \& Vrakking, B. (2006). Homo zappiens: Growing up in a digital age. London: Network Continuum Education.

\section{Appendix 1: Open-ended questions}

\section{Staff open-ended questions}

Q27. Do you have any other comments about use of MyLO, support for MyLO or your need for training?

Q36. Are there other UTAS-provided learning technologies or online services that you use to interact with, or teach, your students that you would like to make comments on?

Q39. Any other comments on e-learning policy, guidelines and quality at UTAS?

Q40. Any other comments on the suitability of teaching spaces to support technologysupported teaching at UTAS?

Q41. Any other comments on training and support for e-learning at UTAS?

Q42. Any other comments on the students experience of learning with technology at UTAS?

\section{Student open-ended questions}

Q23. Any other comments about the IT services or support provided by UTAS?

Q24. Any other comments about the use of MyLO, Lectopia and Turnitin?

Q25. Any other comments or suggestions about how UTAS could improve your learning experiences through better use of technology and online services? 


\section{Appendix 2: Respondent demographics}

Table A2-1: Age and gender distribution of respondents

\begin{tabular}{|l|c|c|c|c|}
\hline \multirow{4}{*}{ Age range } & \multicolumn{2}{|c|}{ Students (n=2361) } & \multicolumn{2}{c|}{ Staff (n=267) } \\
\cline { 2 - 5 } & & $\%$ of sample & & $\%$ of sample \\
\cline { 2 - 5 } & $<18-19$ & $12 \%$ & $<30$ & $15 \%$ \\
\cline { 2 - 5 } & $20-21$ & $22 \%$ & $30-39$ & $24 \%$ \\
\cline { 2 - 5 } & $22-23$ & $15 \%$ & $40-49$ & $34 \%$ \\
\cline { 2 - 5 } & $24-25$ & $10 \%$ & $50-59$ & $18 \%$ \\
\cline { 2 - 5 } & $26-30$ & $11 \%$ & 60 and over & $9 \%$ \\
\cline { 2 - 5 } & Over 30 & $29 \%$ & & \\
\hline \multirow{4}{*}{ Gender } & Male & $41 \%$ & Male & $51 \%$ \\
\cline { 2 - 5 } & Female & $59 \%$ & Female & $49 \%$ \\
\hline
\end{tabular}

Table A2-1 shows the demographics of student and staff respondents. The cut-off for Net Generation aged individuals (born in 1983, or later, that is 26 years of age in 2009) is just inside the age category of 26-30 years for students, which means that somewhere between $59 \%$ and $71 \%$ of students are Net Generation aged, but the figure is almost certainly closer to $59 \%$. This leaves a considerable minority of mature aged students. The cut-off of 26 years of age bisects the 'Under 30' age category for staff, which means that a proportion of somewhere less than $15 \%$ of staff were Net Generation aged.

Table A2-2: Year of study for student sample, and faculty breakdown for staff

\begin{tabular}{|l|l|c|l|c|}
\hline \multicolumn{2}{|c|}{ Student } & \multicolumn{2}{c|}{ Staff faculty or division } \\
\hline \multirow{3}{*}{$\begin{array}{l}\text { Year of } \\
\text { study }\end{array}$} & 1 & $\%$ of sample* & \multicolumn{1}{c|}{ Count } \\
\cline { 2 - 5 } & 2 & $43 \%$ & Arts & 31 \\
\cline { 2 - 5 } & 3 & $24 \%$ & Australian Maritime College & 20 \\
\cline { 2 - 5 } & 4 & $17 \%$ & Business & 18 \\
\cline { 2 - 5 } & 5 & $9 \%$ & Education & 22 \\
\cline { 2 - 5 } & More & $3 \%$ & Finance \& Administration & 10 \\
\cline { 2 - 5 } & & $3 \%$ & Health Sciences & 43 \\
\hline \multirow{4}{*}{$\begin{array}{l}\text { Sode of } \\
\text { study }\end{array}$} & Full time & $69 \%$ & Law & 76 \\
\cline { 2 - 5 } & Part time & $19 \%$ & Student \& \& Education & 7 \\
\cline { 2 - 5 } & Distance/ online & $13 \%$ & Other & 36 \\
\hline
\end{tabular}

${ }^{*}$ Rounding results in total $<100 \%$

Table A2-2 shows the number of years student respondents have been studying and a breakdown of staff by faculty or division. The survey sample is representative of a cross-section of disciplines. Respondents included in 'other' include staff from the Division of Research and from International Services, many of whom teach specialist courses. Table A2-3 shows student responses to a question about the proportion of time spent on four categories of activities.

Table A2-3: Percentage of student respondents and the proportion of time spent on a range of activities

\begin{tabular}{|l|c|c|c|c|c|}
\hline \multirow{2}{*}{ Activity } & \multicolumn{5}{c|}{ Number of hours spent on activity per week } \\
\cline { 2 - 6 } \multicolumn{1}{|c|}{} & $0-10$ & $11-20$ & $21-30$ & $31-40$ & $40+$ \\
\hline Studying & $30 \%$ & $32 \%$ & $20 \%$ & $13 \%$ & $6 \%$ \\
\hline Caring for dependents & $75 \%$ & $7 \%$ & $3 \%$ & $3 \%$ & $11 \%$ \\
\hline Working & $57 \%$ & $22 \%$ & $8 \%$ & $10 \%$ & $3 \%$ \\
\hline On campus & $34 \%$ & $34 \%$ & $17 \%$ & $9 \%$ & $6 \%$ \\
\hline
\end{tabular}


Authors: Mr Gerry Kregor (corresponding author), Senior Educational Developer

Tasmanian Institute of Learning and Teaching (TILT)

University of Tasmania, Private Bag 133, Hobart TAS 7001

Email: Gerry.Kregor@utas.edu.au

Web: http: / / www.utas.edu.au/calt/ and http:/ / www.teaching-learning.utas.edu.au /

Dr Monique Breslin

Tasmanian Institute of Learning and Teaching, University of Tasmania

Email: Monique.Breslin@utas.edu.au

Ms Wendy Fountain, Educational Developer

Tasmanian Institute of Learning and Teaching, University of Tasmania

Email: Wendy.Fountain@utas.edu.au

Please cite as: Kregor, G., Breslin, M. \& Fountain, W. (2012). Experience and beliefs of technology users at an Australian university: Keys to maximising e-learning potential. Australasian Journal of Educational Technology, 28(8), 1382-1404.

http:/ / www.ascilite.org.au/ajet/ajet28/ kregor.html 